University of Nebraska - Lincoln

DigitalCommons@University of Nebraska - Lincoln

$11-27-2012$

\title{
THE ECONOMIC COSTS OF TAX POLICY UNCERTAINTY: IMPLICATIONS FOR FUNDAMENTAL TAX REFORM
}

Seth H. Giertz

University of Nebraska-Lincoln, sgiertz2@unl.edu

Jacob Feldman

George Mason University

Follow this and additional works at: https://digitalcommons.unl.edu/econfacpub

Part of the Econometrics Commons, and the Public Economics Commons

Giertz, Seth H. and Feldman, Jacob, "THE ECONOMIC COSTS OF TAX POLICY UNCERTAINTY:

IMPLICATIONS FOR FUNDAMENTAL TAX REFORM" (2012). Economics Department Faculty Publications.

80.

https://digitalcommons.unl.edu/econfacpub/80

This Article is brought to you for free and open access by the Economics Department at DigitalCommons@University of Nebraska - Lincoln. It has been accepted for inclusion in Economics Department Faculty Publications by an authorized administrator of DigitalCommons@University of Nebraska - Lincoln. 


\section{MERCATUS RESEARCH}

\section{THE ECONOMIC COSTS OF TAX POLICY UNCERTAINTY: IMPLICATIONS FOR FUNDAMENTAL TAX REFORM}

Seth H. Giertz and Jacob Feldman

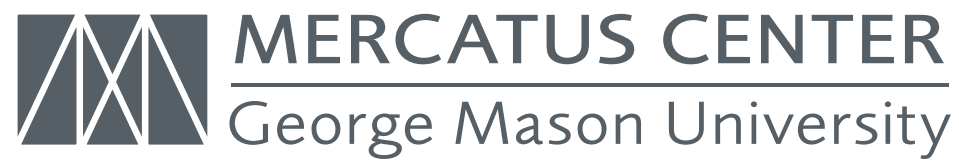

Bridging the gap between academic ideas and real-world problems 


\section{ABOUT THE MERCATUS CENTER AT GEORGE MASON UNIVERSITY}

The Mercatus Center at George Mason University is the world's premier university source for market-oriented ideas-bridging the gap between academic ideas and real-world problems.

A university-based research center, Mercatus advances knowledge about how markets work to improve people's lives by training graduate students, conducting research, and applying economics to offer solutions to society's most pressing problems.

Our mission is to generate knowledge and understanding of the institutions that affect the freedom to prosper and to find sustainable solutions that overcome the barriers preventing individuals from living free, prosperous, and peaceful lives.

Founded in 1980, the Mercatus Center is located on George Mason University's Arlington campus.

www.mercatus.org 


\section{ABOUT THE AUTHORS}

SETH H. Giertz is an assistant professor of economics at the University of NebraskaLincoln. He worked for the Congressional Budget Office's tax division from 2001 to 2008. In 2005, while on leave from CBO, Giertz served as a staff economist for the President's Advisory Panel on Federal Tax Reform.

JACOB FELDMAN is a research analyst with the Mercatus Center at George Mason University. He received his MA in economics from George Mason University. His research interests emphasize federal and state tax policy.

\section{ACKNOWLEDGMENTS}

The Authors would like to thank Jason Fichtner, Jim Musser, Ted Bolema, Emily Washington and two anonymous reviewers for helpful comments. 


\section{ABSTRACT}

THE U.S. FACES tremendous short-term policy uncertainty, including about \$5.4 trillion in tax increases over the next decade. These changes are set to take effect on January 1, 2013. It is unlikely that these changes will fully materialize, but what will happen is anyone's guess. Over the long term, uncertainty also looms large since the U.S. federal tax system is expected to bring in far less revenue than Congress is projected to spend. In this paper, we detail the tax policy uncertainty that the U.S. faces and the economic literature to assess how this uncertainty may be affecting the economy. We then build on this literature by posing an additional avenue through which policy uncertainty may harm the economy. We argue that uncertainty fosters rent-seeking, which represents a shift between productive and unproductive or destructive entrepreneurship. We present a simple empirical model that lends support to our hypothesis. We then discuss principles for tax reform that could result in more stable tax policy.

JEL codes: D72, E62, H2, J24, L26 
I

$\mathrm{N}$ THE NEAR term, individuals and businesses face substantial uncertainty from a host of tax policy changes that are set to take effect on January 1, 2013. The expiration of the so-called Bush tax cuts are the most significant of these scheduled tax changes. Tax rates are scheduled to go up, but such increases are far from certain. The United States faced a similar situation in late 2010, when the Bush tax cuts were initially set to expire. ${ }^{1}$ Instead of resolving the issue, perhaps by permanently extending the tax cuts or allowing them to expire, Congress and the President kicked the can down the road, resulting in a reprise today of the 2010 debate.

Adding to the current confusion is uncertainty regarding the alternative minimum tax (AMT). The AMT is not automatically indexed for inflation and is projected to account for a growing share of federal revenues. However, Congress has prevented much of these tax increases through ad hoc "patches" that are generally enacted at the end of each year and apply only to that year.

In addition to the expiration of the Bush tax cuts and the AMT patch, other temporary tax provisions are set to expire. A two-percentage-point federal payroll tax cut is one such provision. It was set to expire at the end of 2011 and was not fully extended for 2012 until after the year had begun. Furthermore, some taxes from the Affordable Care Act (ACA) are set to take effect in 2013, with others to take effect in later years. For example, ACA surtaxes on some high-income taxpayers are set to begin in 2013. ${ }^{2}$ As enacted, the individual mandate (i.e., the "tax" for failing to obtain health insurance) is set to start at the beginning of the following year, in 2014. However, the tax is so low that it will be advantageous for many uninsured to pay the tax and forego insurance until they need it. ${ }^{3}$ For the health insurance exchanges to function well and keep costs down, it will likely be necessary to substantially raise these taxes. The only thing that is certain is that any debate over the tax issue will be contentious and heated.

1. See Jason J. Fichtner and Katelyn Christ, "Uncertainty and Taxes: A Fatal Mix" (working paper, Mercatus Center, George Mason University, Arlington, VA, 2010).

2. These tax increases seem more certain now that President Obama has been re-elected. However, both Democrats and Republicans have been reluctant to raise taxes while the economy remains in the doldrums following the Great Recession.

3. Martin Feldstein, “Obamacare's Nasty Surprise,” Washington Post, November 6, 2009, http://www.nber.org/feldstein/washingtonpost_110909.html. 
Over the longer term, uncertainty also looms large. In the coming decades, the U.S. federal tax system is expected to bring in far less revenue than Congress is projected to spend. Either major changes are needed to rein in programs such as Medicare, Medicaid, and Social Security, or major tax increases are needed-or a combination of the two approaches. Longtime budget expert Robert Reischauer (who formerly served as director of the Congressional Budget Office, or CBO, and president of the Urban Institute) states, "The path we're on can't go on for fifteen years. Whether it can go on for two, three, or four years, I have no idea." 4

This near- and longer-term uncertainty is not good for the economy. While good tax policy is always preferred to bad, a growing literature is finding that uncertainty itself has negative implications for the economy, slowing economic growth and possibly prolonging a weak recovery. Policy uncertainty has been shown to reduce investment and to cause firms and individuals to misallocate resources, and all of these things impose costs on society.

In a recent paper, Baker, Bloom, and Davis found that policy uncertainty could explain the United States' poor economic performance in recent years. Their model predicts that policy uncertainty similar to what the U.S. has faced in recent years will result in a lowering of real GDP by 2.2 percent and a loss of 2.5 million jobs. Note that the costs due to uncertainty should be distinguished from the fact that uncertainty may arise from increased prospects for harmful policies. In recent years, these two factors (i.e., uncertainty itself and the increased likelihood of inferior economic policy) have often been positively correlated. While policy uncertainty imposes economic costs, so too does a certain shift toward a bad policy environment. ${ }^{5}$

In this paper, we detail the tax policy uncertainty that the U.S. currently faces, and we review the academic literature on the effects of policy uncertainty. In addition, we posit that rent-seeking is an additional cost of tax policy uncertainty that is neglected in the literature. We build on the work of Baumol, who contended that although entrepreneurship can be productive, it can also be unproductive or even destructive. We find that policy uncertainty increases the expected returns from rent-seeking and thus yields more of this unproductive or destructive entrepreneurship. An empirical model is developed to examine this hypothesis. We conclude by arguing that fundamental tax reform is an important step toward reducing tax policy uncertainty. However, special attention must be paid to designing a reform that will be enduring, as opposed to one that is undone through rent-seeking.

4. David Wessel, Red Ink: Inside the High-Stakes Politics of the Federal Budget (New York: Crown Business, 2012), 29.

5. For example, if the U.S. were certain to pass over the "fiscal cliff" discussed in the next section, the costs to the economy would likely be large. 


\section{SHORT-TERM AND LONG-TERM TAX POLICY UNCERTAINTY}

The Bush TAX cuts refer to a series of bills passed in 2001, 2003, and 2004. ${ }^{6}$ These tax cuts were, for the most part, extended two additional years by the Tax Relief, Unemployment Insurance Reauthorization, and Job Creation Act (TRUIRJCA) of 2010, which brings us to the so-called "fiscal cliff" at the end of 2012. The hallmark of the expiring tax provisions is the reduction of individual income tax rates for nearly all federal income tax brackets. However, tax provisions affecting capital gains, dividends, estates, payroll taxes, and the AMT, as well as a host of tax credits, deductions, and phaseouts, are all set to change in 2013. Other legislation, such as the American Recovery and Reinvestment Act (ARRA) of 2009, includes important tax provisions that often carry the same expiration date as the Bush tax cuts. CBO (2012) projects that federal revenues will increase by an additional $\$ 5.4$ trillion over the next ten years if all tax cuts expire. ${ }^{7}$

The 1974 Congressional Budget Act created CBO and the process for assessing the budget implications of proposed legislation. These budget rules, intended to impose more prudent fiscal policy, are often gamed by politicians. As a result, they sometimes yield policy uncertainty and policies that are less desirable than had the rules not been in place. ${ }^{8}$ As former CBO Director Rudy Penner noted in 1990, "we have a [budget] process that looks very elegant on paper, but is leading to very dishonest and disorderly results...[I]t has done an enormous amount of harm in spawning a large number of gimmicks that make it very difficult to analyze the budget anymore. These gimmicks make investors and other outsiders lose confidence in the government." More than two decades later, Penner's critique still has merit.

The passage of the Bush tax cuts is a case in point. Because the Bush tax cuts were passed via Congress's reconciliation process (which stems from the Budget Act), they were subject to the "Byrd Rule," which requires that any tax or spending bill passed via reconciliation not adversely affect the federal deficit in years outside the ten-year budget window..$^{10}$ As a result, instead of pushing permanent legislation that would offset the reduction in revenues with cuts in spending growth, Congress proposed temporary legislation, in the hope that it would be made permanent later. ${ }^{11}$

6. These include the Economic Growth and Tax Relief Reconciliation Act (EGTRRA) of 2001, the Jobs and Growth Tax Relief Reconciliation Act (JGTRRA) of 2003, and the Working Families Tax Relief Act (WFTRA) of 2004.

7. The Budget and Economic Outlook: Fiscal Years 2012 to 2022, January 2012 (Washington, DC: Congressional Budget Office), http://www.cbo.gov/sites/default/files/cbofiles/attachments/01-31-2012_Outlook.pdf.

8. See Allen Schick and Felix Lostracco, The Federal Budget: Politics, Policy, Process, rev. ed. (Washington, DC: Brookings Institution Press, 2000).

9. Louis Fisher, Congressional Abdication on War and Spending (College Station, TX: Texas A\&M University Press, 2000), 24.

10. Since there was not enough support for the Bush tax cuts to overcome a filibuster in the Senate, reconciliation was the only viable option.

11. See "Why Are the Bush Tax Cuts Expiring?" May 26, 2010, Tax Foundation: Washington, DC, http://taxfoundation.org/article/why-are-bush-tax-cuts-expiring. 
The Bush tax cuts also employed the common practice of phasing in the cuts over several years, so that that the negative impact on the deficit would be reduced in the early years, making projections over the ten-year budget window more appealing than they would be for fully phased-in legislation. Thus, it is possible that the Budget Act has yielded diminished fiscal responsibility and greater policy uncertainty. CBO and the Joint Committee on Taxation (JCT) produce cost estimates for proposed legislation, but because Congress sets the rules of the game and then manipulates legislation accordingly, the Budget Act may provide a false sense of due diligence. Thus, while it is possible that the Budget Act has had a positive impact on the budget process and policy outcomes, such a statement is at least debatable. ${ }^{12}$

\section{Details on Expiring Legislation}

FOR MORE THAN a decade, Congress has relied on temporary or short-term fiscal policy, resulting in an array of tax provisions that are set to expire at the end of 2012..$^{13}$ The expiration of these policies will amount to a sharp tax increase. ${ }^{14}$ First, the Bush tax cuts passed in 2001, 2003, and 2004 decreased rates on earned income (as well as on capital gains and dividends) for nearly all taxpayers. The expiration of these cuts will lower personal exemptions, while reintroducing the phaseout of personal exemptions and itemized deductions. It will also increase capital gains and dividend tax rates, increase the estate tax rate (while lowering the exemption), and remove a host of other credits, deductions, and deduction limitations. The fact that the tax cuts were first set to expire at the end of 2010 has likely contributed to the recent increase in tax policy uncertainty shown in Figure 1. The expiration of these provisions is projected to increase tax revenues by $\$ 2.84$ trillion over 10 years (Table 1 ).

Second, the most recent patch to the AMT, which adjusts the number of taxpayers subject to this tax, expires on January 1, 2013. Without an AMT patch for 2013, an estimated 31 million taxpayers will owe tax under the AMT. According to $\mathrm{CBO}$, if the AMT patch were not renewed, revenues would increase by $\$ 952$ billion over ten years, and 26 million more taxpayers would be subject to the tax in 2012 (Table 1). ${ }^{15}$ The current patch reduces the number of affected tax filers from

12. For a critical view of the budget process, see Louis Fisher, Testimony before the Senate Committee on the Budget, "Improving the Congressional Budget Process," October 12, 2011, http://www.constitutionproject.org/pdf/101211_congressionalbudgetprocess_congressionaltestimony.pdf.

13. For an in-depth review of expiring tax provisions, see Margot L. Crandall-Hollick, "An Overview of Tax Provisions Expiring in 2012," CRS Report for Congress, April 2012 (Washington, DC: Congressional Research Service).

14. On top of this, large and seemingly arbitrary cuts in spending are set to take effect, resulting from the failure of the so-called Super Committee set up by the 2011 Budget Control Act.

15. The Budget and Economic Outlook: Fiscal Years 2012 to 2022, January 2012 (Washington, DC: Congressional Budget Office), http://www.cbo.gov/sites/default/files/cbofiles /attachments/01-31-2012_Outlook.pdf. 
31 million to 4.3 million. ${ }^{16}$ When the current AMT was created in $1982,{ }^{17}$ only 155 high-income households faced the tax. Because the AMT is not indexed for inflation (unlike brackets for the regular income tax, which are indexed), it hits taxpayers with lower and lower real incomes each year. AMT liability equals the person's tax liability calculated under the AMT minus their liability calculated under the regular federal income tax, if positive. By lowering tax liabilities under the regular federal income tax, the Bush tax cuts increased tax liabilities under the AMT. To offset this, the Bush tax cuts included an AMT patch, but only for four years. Since 2006, the AMT patch has, for the most part, been adjusted on a yearly basis without any guarantee of its extension.

Congress's failure to seriously address the AMT is another artifact of the Budget Act and related rules for assessing bills. One- or two-year patches, on paper, require the government to forego revenue in only one or two years of the ten-year budget window. All else being equal, if Congress passes a one-year patch for ten straight years, the effect (over the ten-year period) would be the same as a change that permanently indexed the AMT. However, because CBO and JCT are required to assume a current law baseline when assessing legislation, continual ad hoc changes will always look better on paper. ${ }^{18}$ In the coming weeks, it is possible that Congress will not act, or that Congress will renew some type of patch-or even abolish or permanently index the AMT for inflation. Thus, the fate of this tax is a major source of policy uncertainty, which may itself impose economic costs.

\section{TABLE 1. MAJOR TAX PROVISION SET TO EXPIRE}

\begin{tabular}{|l|l|l|l|}
\hline Tax Provision & Originally Enacted & $\begin{array}{l}\text { Length of Prior } \\
\text { Extension }\end{array}$ & Ten-Year Revenue Est. \\
\hline $\begin{array}{l}\text { EGTRRA and JGTRRA } \\
\text { (the Bush tax cuts) }\end{array}$ & 2001 and 2003 & Two Years & $\$ 2.84$ trillion* \\
\hline AMT Patch & 2006 & One Year & $\$ 804$ billion \\
\hline Payroll Tax Cut & 2010 & One Year & $\$ 114$ billion (2012 only) \\
\hline Other Tax Extenders & 2008 & One Year & $\$ 839$ billion \\
\hline
\end{tabular}

Source: $C R S, C B O$

*Debt service associated with the Bush tax cuts and AMT patch is an additional $\$ 790$ billion between 2013 and 2022

Third, the two-percentage-point payroll tax cut enacted as part of the December 2010 tax bill-which itself was intended to replace the two-year-old Making Work Pay tax credit-also expires after 2012. This tax cut reduced the employee share of

16. Tax Policy Center, “Alternative Minimum Tax: What is the AMT?”, http://www.taxpolicycenter .org/briefing-book/key-elements/amt/what-is.cfm.

17. An alternativ3 minimum tax was created in 1969.

18. The baseline is the scenario that is used for reference when measuring the revenue or expenditure implications of legislation. For its official revenue estimates, CBO and JCT are not permitted to make predictions concerning future actions by Congress. Rather, they are to assume that the laws on the books will not change. For example, they are not to assume that Congress will extend the AMT patch, even though it has done so for many consecutive years. 
Social Security payroll taxes in 2011 from 6.2 percent to 4.2 percent. Originally, the payroll tax cut was presented as a one-year fiscal stimulus, but it was extended for part of 2012 on a last-minute vote in December 2011; in 2012, it was extended for the remainder of the year. It is unknown whether this provision will be extended for the coming year as well. CBO estimates that foregone revenue from this tax cut will total $\$ 225.7$ billion for 2011 and 2012. ${ }^{19}$

Fourth, a hodgepodge of other tax extenders is also expiring. Different groups define "tax extenders" differently: for example, some consider the Bush tax-cut extensions and the AMT patches to be tax extenders, while others include only miscellaneous tax provisions in that category. Here we define "tax extenders" as regularly recurring tax extensions that have not already been addressed; more specifically, we use the term to refer to a group of 80 or so temporary tax provisions slated to expire within 10 years. ${ }^{20} \mathrm{JCT}$ breaks down expiring provisions by the year in which the legislation is set to expire. ${ }^{21}$ Examples of tax extenders are the deduction of state and local sales taxes, the research and experimentation tax credit, and incentives for alcohol fuels, as well as more obscure provisions, such as the Indian Employment Tax Credit. ${ }^{22} \mathrm{CBO}$ (relying on analysis from JCT) projects that a tenyear extension of these tax extenders would lower revenues by $\$ 839$ billion, in addition to $\$ 173$ billion of added debt service-that is, additional interest payments resulting from increased government borrowing. ${ }^{23}$

Prior to the 2012 elections, President Obama had expressed interest in permanently extending most of the Bush tax cuts, with the major exception being married filers with incomes over $\$ 250,000$ (and singles over $\$ 200,000$ ) who would see their tax rates rise for ordinary income, as well as capital gains and dividends. This group includes those in the top tax bracket (35 percent for 2012) and many in the second highest tax bracket (33 percent for 2012). Many Republicans have been unwilling

19. For government accounting purposes, general revenues are credited to Social Security to make up for revenue losses from the payroll tax cut.

20. See, for example, Table 2 in Margot L. Crandall-Hollick, "An Overview of Tax Provisions Expiring in 2012,” April 17, 2012 (Washington, DC: Congressional Research Service), http://www.fas.org /sgp/crs/misc/R42485.pdf.

21. Joint Committee on Taxation, “List of Expiring Federal Tax Provisions 2011-2022," January 13, 2012, JCX-1-12: Washington, DC, https://www.jct.gov/publications.html?func=download\&id=43 83\&chk=4383\&no_html=1; for revenue estimates, see Congressional Budget Office, "Expiring Tax Provisions-January 2012 Baseline,” January 31, 2012. Many of the numbers presented by CBO are provided to CBO by JCT.

22. See Table 1 in Margot L. Crandall-Hollick, "An Overview of Tax Provisions Expiring in 2012," April 17, 2012 (Washington, DC: Congressional Research Service), http://www.fas.org/sgp/crs/misc /R42485.pdf.

23. See page 21 of The Budget and Economic Outlook: Fiscal Years 2012 to 2022, January 2012 (Washington, DC: Congressional Budget Office), http://www.cbo.gov/sites/default/files/cbofiles /attachments/01-31-2012_Outlook.pdf.

24. Lindsey Boerma, "Obama: GOP, Dems Agree on Middle-Class Tax Cut Extension," CBS News, July 14, 2012, http://www.cbsnews.com/8301-503544_162-57472427-503544/obama-gop-dems-agree -on-middle-class-tax-cut-extension/. 
to extend the tax cuts unless the top tax brackets are included. ${ }^{24}$ If the stalemate persists, tax rates will revert to pre-2001 levels for all brackets.

\section{Long-Run Policy Uncertainty}

WHILE THE U.S. faces tremendous short-term policy uncertainty, the long-term outlook is no better. None of the scenarios likely to occur prior to 2013 addresses the nation's long-term fiscal problems, so the one thing that seems clear going into 2013 is that policy uncertainty will continue to be a major issue. For many years, and predating the Great Recession, economists and other policy analysts have warned that the government's taxing and spending policies are unsustainable. ${ }^{25}$ Long-run spending commitments are out of line with long-run revenue projections, given anything resembling current tax policy (or historical measures of tax revenue as a share of GDP). For more than a decade, special bipartisan commissions have proposed reforms for areas such as Social Security, tax policy, and the nation's overall fiscal position. ${ }^{26}$ Despite these efforts, Congress has not acted on any of these recommendations. To the extent that Congress and the President do act, it is often to worsen the long-term fiscal outlook. For one example, consider the 2003 bill that expanded prescription drug coverage to Medicare ${ }^{27}$ Other scholars make similar arguments regarding President Obama's health-care legislation-the 2010 Patient Protection and Affordable Care Act (ACA). ${ }^{28}$ See, for example, Blahous or Holtz-Eakin and Capretta. ${ }^{29}$

Lawrence Kotlikoff, Richard Evans, and Kerk Phillips estimate that the fiscal gap, which measures the difference between spending obligations and expected revenues, is a staggering $\$ 211$ trillion in present value terms. By comparison, annual U.S. GDP is about $\$ 15$ trillion. In order to address this imbalance, either taxes would

25. In a 2005 interview with C-SPAN's Brian Lamb, then-CBO Director Douglas Holtz-Eakin flippantly remarked that "I often say to people, you know, these are good old days, enjoy it" (see http://www.q-and-a.org/Transcript/?ProgramID=1051). Holtz-Eakin was not the first CBO director to warn of the nation's long-term fiscal problems. Such warnings became then-Government Accountability Office Director David Walker's primary mission. Dating back to at least 1993, Peter G. Peterson has warned of the unsustainability of the U.S.'s entitlement programs. See Peter G. Peterson, Facing Up: How to Rescue the Economy from Crushing Debt and Restore the American Dream (New York: Simon \& Schuster, 1993).

26. President Bush established the Commission to Strengthen Social Security as well as the President's Panel on Federal Tax Reform. Congress established the National Commission on Fiscal Responsibility and Reform (also known as the Bowles-Simpson Commission).

27. That is, the Medicare Prescription Drug, Improvement, and Modernization Act.

28. The ACA remains a highly partisan issue, and highly respected economists disagree on its net fiscal impact.

29. Charles Blahous, "The Fiscal Consequences of the Affordable Care Act," April 10, 2012, Mercatus Center, http://mercatus.org/sites/default/files/publication/The-Fiscal-Consequences-of-theAffordable-Care-Act_1.pdf; Douglas Holtz-Eakin and James C. Capretta, "Resetting the 'Obamacare' Baseline,” Politico.com, December 16, 2010, http://www.politico.com/news/stories/1210/46428.html.

30. National Public Radio (NPR), “A National Debt of \$14 Trillion? Try \$211 Trillion,” August 6, 2011, http://www.npr.org/2011/08/06/139027615/a-national-debt-of-14-trillion-try-211-trillion.

31. Richard W. Evans, Laurence J. Kotlikoff, and Kerk L. Phillips, "Game Over: Simulating Unsustainable Fiscal Policy” (working paper, NBER, 2012). 
have to be permanently increased by 64 percent $^{30}$ or spending would need to be cut by 40 percent. ${ }^{31}$ If the gap is filled solely by raising taxes, tax revenues would rise to 26.7 percent of GDP, or roughly 50 percent above the post-World War II average of 17.7 percent. ${ }^{32}$ The key driver of the fiscal gap is entitlement spending, and particularly government spending on health care (e.g., Medicare).

The U.S. spent (from government and private sources) about 18 percent of GDP on health care in 2011. For many years, spending on health care has grown much more rapidly than the overall economy. Because government plays a large and growing role in financing health care, this trend has placed great strain on government budgets. ${ }^{33}$ Depending on the fiscal constraints utilized by the federal government, CBO estimates that Medicare spending will grow to 6.7 percent of GDP by 2037 while Medicaid, the Children's Health Insurance Program, and the Affordable Care Act's subsidized exchanges are projected to reach 3.7 percent of GDP. ${ }^{34}$ This does not include tax expenditures that are used to subsidize health care and health insurance; such subsidies totaled $\$ 187$ billion for $2011 .{ }^{35}$ Similarly, Social Security outlays are expected to increase from 5.0 to 6.2 percent of GDP by $2037 .{ }^{36}$ The trajectory for these programs poses serious problems, further exacerbated by the fact that the federal government continued to run substantial deficits prior to 2012, and even prior to the Great Recession. If the fiscal imbalances continue to go unaddressed, payments on debt obligations will grow rapidly. CBO's ten-year outlook estimates that debt servicing as a percentage of GDP will rise a full percentage point by 2022, with further increases projected after that year. ${ }^{37}$

32. Author calculations are based on the Congressional Budget Office's The Budget and Economic Outlook: Fiscal Years 2012 to 2022, http://www.cbo.gov/sites/default/files/cbofiles/attachments/01-31-2012_Outlook.pdf, and on the Office of Management and Budget's 2012 Historical Tables, "Table 1.2-Summary of Receipts, Outlays, and Surpluses or Deficits as Percentages of GDP: 1930-2017," http://www.whitehouse.gov/sites/default/files/omb/budget/fy2013/assets/hist01z2. xls. Due to chronic deficits, post-WWII federal spending as a share of the economy is over 2 percentage points higher than tax revenues as a share of the economy.

33. Some argue that the causation is reversed and that it is this government involvement that is a major driver in health-care spending.

34. The 2012 Long-Term Budget Outlook, June 2012, p. 49 (Washington, DC: Congressional Budget Office), http://www.cbo.gov/sites/default/files/cbofiles/attachments/LTBO_One-Col_2.pdf.

35. Authors' calculations are based on the Fiscal Year 2013 Analytical Perspectives, Budget of the U.S. Government, published by the Office of Management and Budget, http://www.whitehouse.gov/ sites/default/files/omb/budget/fy2013/assets/receipts.pdf.

36. The 2012 Long-Term Budget Outlook, June 2012, p. 71 (Washington, DC: Congressional Budget Office), http://www.cbo.gov/sites/default/files/cbofiles/attachments/LTBO_One-Col_2.pdf.

37. The Budget and Economic Outlook: Fiscal Years 2012 to 2022, January 2012, p. 50 (Washington, DC: Congressional Budget Office), http://www.cbo.gov/sites/default/files/cbofiles/attachments/01-31-2012_Outlook.pdf. 


\section{Baker, Bloom, Davis Policy Uncertainty Index}

Scott BaKer, Nicholas Bloom, and Stephen Davis (henceforth BBD) produce several indices measuring uncertainty, most of which date back to $1985{ }^{38}$ They include indices for policy-related economic uncertainty and financial uncertainty, as well as an overall uncertainty index and an index measuring tax policy uncertainty (based on expiring tax legislation). ${ }^{39}$ We use these indices for historical perspective. Later, we will examine the relationship between some of these uncertainty measures and rent-seeking.

For our purposes, one shortcoming of the BBD measures is that their tax measure only extends back to 1998. Several of their other measures are based on Google News searches and, as mentioned above, extend back to $1985 .{ }^{40}$ By contrast, the BBD tax measure is based on expiring tax legislation reported by JCT, which extends back to just 1998. In order to obtain a measure back to 1985 (which is important to our analysis later in the paper), we construct our own tax policy uncertainty index following the same approach laid out by BBD for their other Google News-based measures.

For our measure of tax policy uncertainty, we calculate the number of hits by month from Google News searches. We scale this measure by dividing by the number of times an analogous Google News search turns up the word "today." Our index spans from January 1985 to October 2011. We search for the terms "federal"

38. Scott R. Baker, Nicholas Bloom, and Steven J. Davis, "Measuring Economic Policy Uncertainty"(working paper, 2011).

39. BBD indices were created using a variety of techniques and sources for data, depending on the component of the index. The monthly economic policy uncertainty index comes from using a combination of three weighted inputs: $1 / 2$ for broad news-based policy uncertainty, $1 / 6$ for a tax expiration index, $1 / 6$ for forecasted disagreement on the inflation rate (as measured by the Consumer Price Index, or CPI), and $1 / 6$ for forecasted federal purchases disagreement. Each measured component was normalized by its own standard deviation. Some indices used by BBD were generated by normalizing the Google News searches on particular keywords with a backward-looking 36-month moving average. For example, the policy-related economic uncertainty index was created through a search of terms containing "uncertain" or "uncertainty," "economic" or "economy," and one of more of the following terms: "policy," "tax," "spending," "regulation," "federal reserve," "budget," or "deficit." The monthly index generated by BBD for discounting expiring tax legislation is weighted accordingly: $0.5^{(\mathrm{T}+1) / 22)}$, where $\mathrm{T}$ is equal to the number of months in the future that the tax provision expires. Dispersion of forecasts in the CPI and federal expenditures are treated as proxies for economic uncertainty, as in most prior economic literature. Economic data for the economic-policy uncertainty index was collected from the Joint Committee on Taxation and the Federal Reserve Bank of Philadelphia's Survey of Professional Forecasters. These data are publically accessible at www.policyuncertainty.com.

40. These Google News searches were conducted on a month-by-month basis between January 1985 and October 2011. Each search was related to news measurements of economic, financial, and policy uncertainty. To set a value for each Google index, the raw count of article results is scaled by the number of Google News articles that use the word "today." The search results are normalized due to a rising number of articles appearing online since 1985 (a 600 percent increase, according to $\mathrm{BBD})$. This measure is then normalized to 100 for the first period of data. Like Baker, Bloom and Davis, we utilize a backward-looking 36-month moving average to smooth the monthly data and remove high-frequency noise. 
and "taxes" with "uncertain" or "uncertainty." As with BBD's measures, we scale the raw article to account for the rising number of articles that appeared online between 1985 and 2011. Our monthly and yearly news-based tax uncertainty indices are graphed against BBD's general economic uncertainty and policy uncertainty indices, as well as their measure of expiring tax provisions (Figure 1). Our tax uncertainty index exhibits the same general pattern as the measure of expiring tax provisions, but the fluctuations over the past decade are nuanced by comparison. In general, our uncertainty measure is more stable than the other news-based measures produced by BBD. While we attempt to mirror their approach, it is possible that there are slight differences.

FIGURE 1. UNCERTAINTY INDICES AND TAX EXPIRATION

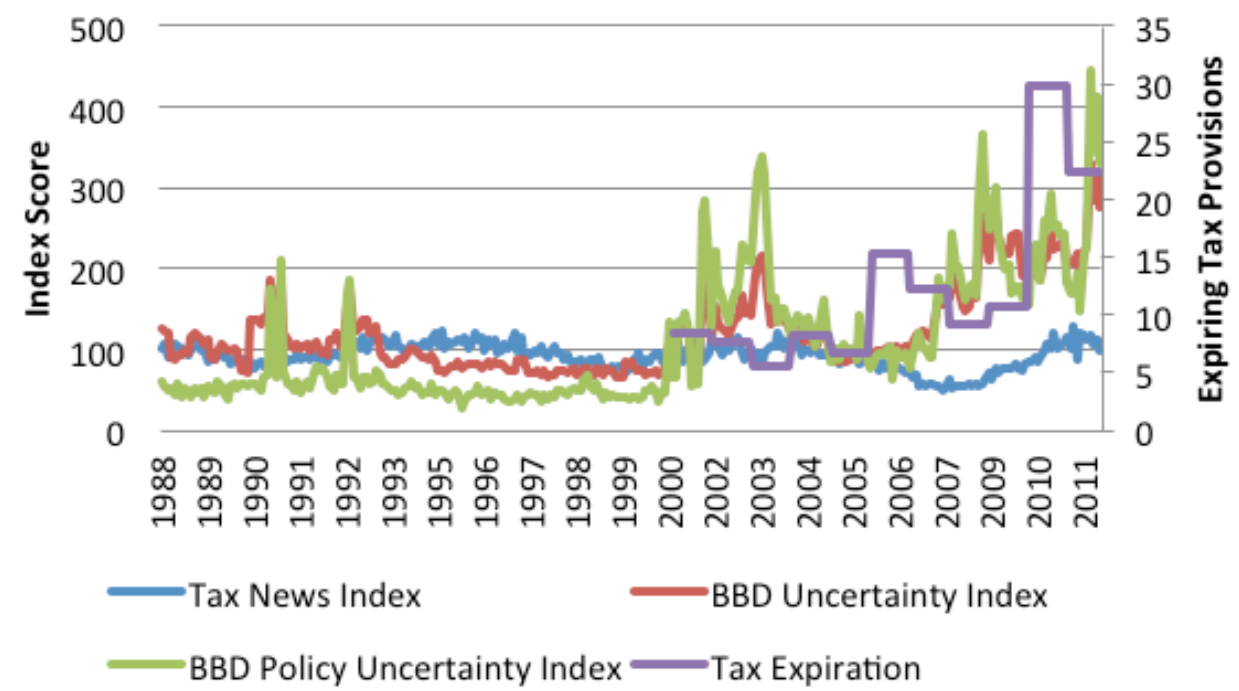

Sources: BBD, Google News, Joint Committee on Taxation

BBD argue that over the last ten years policy uncertainty has been a larger component of overall economic uncertainty than in the past. Figure 1 suggests that some of the rise in overall policy uncertainty may be attributed to heightened tax policy uncertainty. BBD's annual measure of tax policy uncertainty is based on counting the number of expiring tax provisions. ${ }^{41}$ However, the number of such tax provisions may not accurately reflect their economic importance, since the dollar value of expiring provisions varies greatly. It's important to note that our index also does not directly measure the economic significance of tax provisions.

In the next section, we will look at the potential economic implications of tax policy

41. This measure is discounted to allow for the time to expiration and also to reflect the fact that many expiring tax provisions are routinely renewed. 
uncertainty and at the relationship between tax policy uncertainty and lobbying, which we use as a proxy for rent-seeking behavior. We will also discuss the literature examining the relationship between policy uncertainty and economic growth.

\section{THE ECONOMIC COSTS OF POLICY UNCERTAINTY}

THERE IS NO consensus on how to best measure policy uncertainty or the magnitude of the associated costs. However, the fact that policy uncertainty adversely affects the economy is well established. We categorize the three main avenues of harm as decision paralysis, resource misallocation, and capital flight (or hibernation) from fear of regime change. We now build on this literature by positing a fourth avenue: increased rent-seeking. We contend that added rent-seeking, triggered by uncertainty, represents an additional drag on the economy, and we believe it is a contributing factor to the overall economic costs of policy uncertainty.

\section{Uncertainty and Economic Performance}

BBD, DISCUSSED IN the previous section, find that policy uncertainty can impose negative effects on investment, consumption (and GDP, of which investment and consumption are primary components), and employment. According to estimates from the BBD model, "an increase in policy uncertainty equivalent to the actual increase from 2006 to 2011 is followed by a decline of about $2.2 \%$ in real GDP and $13 \%$ in private sector investment and an employment drop of around 2.5 million persons." ${ }^{\prime 2}$ BBD find that policy uncertainty accounted for a relatively small share of economic uncertainty in the 1990s but explained a larger portion of it after 9/11. The authors conclude that most movements in overall economic uncertainty in recent years may be attributed to policy uncertainty.

BBD do not examine the process by which uncertainty harms the economy but rather report strong negative correlations between uncertainty measures and economic activity. They note various avenues (addressed in the literature) by which uncertainty imposes economic costs and argue their findings are consistent with these underlying processes. In the next section, we use some of BBD's measures in conjunction with other data to examine one potential avenue by which tax policy uncertainty may impose economic costs. That is, the relationship between uncertainty and rent-seeking, which sheds additional light onto BBD's findings. Our hypothesis does not supplant other avenues through which policy uncertainty affects the economy, but rather is an additional implication of policy uncertainty that, to our knowledge, has not been addressed in the literature.

42. BBD note that ascribing a causal relationship to their results requires strong assumptions. 


\section{Decision Paralysis}

CONSIDER A STYLIZED world in which a venture capitalist is considering two investment alternatives, each requiring substantial sunken (or irreversible) costs. One option is investing in ethanol production, while the other investment is in solar energy. In the ongoing presidential race, one candidate, in an effort to appeal to farm states, promises increased tax subsidies for ethanol. Another presidential candidate, in an effort to appeal to environmentalists, promises a new tax subsidy for solar energy. ${ }^{43} \mathrm{~A}$ venture capitalist, deciding where to invest, produces the following matrix:

\begin{tabular}{|c|c|c|}
\hline \multirow[b]{2}{*}{ Investment } & \multicolumn{2}{|c|}{$\underline{\text { Policy Alternatives }}$} \\
\hline & Ethanol Subsidy & Solar Subsidy \\
\hline Ethanol & profit: $x, y$ & loss: z \\
\hline Solar & loss: z & profit: $x, y$ \\
\hline
\end{tabular}

The first number in each cell is the net return from an investment made ex ante (to the policy decision), whereas the second number is the net return from an investment made ex post. No ex post investment would ever be made in sectors that are not favored, since this would be a sure loser. If $\mathrm{z}$ were to equal 0 , then a rational investor would choose to invest ex ante only if this return were greater than the ex post return divided by the probability that the policy that favors this investment is enacted-that is, if $\mathrm{x} \geq \mathrm{y} / \operatorname{Pr}$ (win). Thus, if each policy is likely to occur with equal probability, then $\mathrm{x}$ must be at least equal to twice the expected ex post return (i.e., y). If $z$ were positive (i.e., not zero), then $\mathrm{x}$ would need to be even larger. While this is a very simple and highly stylized example, it demonstrates how policy uncertainty can lead to decision paralysis.

This example is consistent with the findings of current Fed Chairman Ben Bernanke (1983), who showed that under an "irreversibility" assumption, uncertainty may lead to cyclical investment patterns in which purchasing durable investments is delayed in favor of holding liquid assets. ${ }^{44}$ Similarly, Dani Rodrik (1991) found that policy uncertainty acts as a tax on investment, retarding development in poorer nations.$^{45}$ Coupled with irreversibility, even positive economic reforms are

43. This example highlights the effect of uncertainty on investment decisions and does not consider the merits of either policy.

44. Ben Bernanke, "Irreversibility, Uncertainty and Cyclical Investment," Quarterly Journal of Economics 98 (1983), 85-106.

45. Dani Rodrik, "Policy Uncertainty and Private Investment in Developing Countries," Journal of Development Economics 36 (1991), 229-42. 
of only limited success if it is uncertain that the reforms will remain in place over the long term. ${ }^{46}$

\section{Resource Misallocation}

IN ADDITION TO decision paralysis, policy uncertainty can alter the allocation of resources. This effect extends to firms making investment or hiring decisions, as well as to people making savings and labor market decisions. For risk-averse individuals, uncertainty is likely to alter behavior: People engage in precautionary measures in response to uncertainty. These precautionary measures can be costly and increase the burden on the economy. ${ }^{47}$

Francisco Gomes, Laurence Kotlikoff, and Luis Viceira (2011) examined the impact of resource misallocations resulting from uncertainty. ${ }^{48}$ They employed an overlapping generations model and produced excess-burden calculations to measure the costs of misallocating resources. Gomes et al. focused on the effects of uncertainty (with respect to Social Security and income tax rates) on measures such as wealth, income, consumption, and portfolio allocation over one's life cycle. ${ }^{49}$ Under their baseline assumption, they reported that uncertainty with respect to future tax rates results in a loss equal to 0.03 percent of annual income, when effectively 9 percent of income is subject to uncertainty. This number is sensitive to both the magnitude of the uncertainty (i.e., of potential tax changes) and the level of risk aversion. Gomes et al. conclude "that households experience sizable welfare gains from learning early about future changes in benefits and tax rates regardless of their attitudes toward risk or the uncertainty they face about their own labor earnings."

In a 2012 paper, Ellen McGrattan also found evidence that tax policy uncertainty

46. There is a substantial literature on the impact that irreversibility in conjunction with uncertainty has on investment. In conjunction with uncertainty, irreversibility tends to reduce new investment. However, investments that passed a cost-benefit test in an earlier economic or political environment often cannot be undone in a later environment, even if they no longer appear prudent. That is, it is possible for irreversibility, while reducing investment at the margin, to raise the overall capital stock because of the "hangover" effect that prevents firms from reducing their capital. See Andrew B. Abel and Janice C. Eberly, "The Effects of Irreversibility and Uncertainty on Capital Accumulation," Journal of Monetary Economics 44, no. 3 (1999), 339-77.

47. Excess burden-also known as deadweight loss or welfare loss-is the net loss to society from the misallocation of resources. This is effectively money left on the table and generally results from government distortion of market prices or from external costs or benefits associated with certain goods or services.

48. Francisco Gomes, Laurence J. Kotlikoff, and Luis M. Viceira, "The Excess Burden of Government Indecision," in Tax Policy and the Economy, ed. Jeffrey Brown, vol. 26 (Chicago: NBER, University of Chicago Press, 2011), 125-63.

49. Labor income data are taken from Joao Cocco, Francisco Gomes, and Pascal Maenhout, "Consumption and Portfolio Choice over the Life-Cycle," Review of Financial Studies 18, no. 2 (2005), 491-533. 
retards investment. ${ }^{50}$ She found that uncertainty regarding taxes on individual income, including corporate dividends and undistributed profits, decreased investment significantly during the 1930s. McGrattan wrote that tax policy uncertainty, while not the cause or primary driver of the Great Depression, played a larger role than most believed, and likely both prolonged the Depression and increased its severity. However, in McGrattan's case, it is not just uncertainty per se that influences investment, but also whether the uncertainty involves a potential shift toward a tax policy that is less favorable to investment.

In addition to the impact on economic outcomes, responses to uncertainty may decrease government revenues. Kevin Hassett and Gilbert Metcalf found that uncertainty surrounding U.S. investment tax credits may not have lowered investment but did lower federal revenues..$^{51}$ Expectations regarding investment tax incentives may increase aggregate investment or simply alter the timing of investment without affecting its overall level. McGrattan too reported evidence of intertemporal shifting of investment during the 1930s as a result of uncertainty. Again, the effect of uncertainty is related to the direction in which tax changes might occur. Depending on the interrelationship, uncertainty could even be associated with increased economic activity; however, in general, this would likely be the result of intertemporal shifting and not persistent economic gains.

\section{Capital Flight or Hibernation}

ROBERT HigGS ARGUED that regime uncertainty played a major role in the length and severity of the Great Depression ${ }^{52}$ and that this uncertainty explains the dearth of investment during that time. Higgs noted that it was not until after World War II that these fears were allayed and private investment returned to levels seen in the 1920s. While acknowledging that arguments about the pending end of the U.S. private-enterprise system seem "hyperbolic" in retrospect, Higgs chronicles political and legal events, as well as data from public opinion surveys, to suggest that cataclysmic views were real at the time. One source who exemplified Higgs's point was Herman Krooss, who concluded that "Business leaders sincerely believed that the government was in evil hands... and preparing the way for socialism, communism, or some other variety of anti-Americanism[.]" ${ }^{53}$

Investment (and other economic activity) falters because of fears that property rights are threatened. This is not a cost of uncertainty per se, but a reflection of the

50. Ellen R. McGrattan, “Capital Taxation during the U.S. Great Depression," Quarterly Journal of Economics 127 (2012): 1515-50.

51. Kevin A. Hassett and Gilbert E. Metcalf, "Investment with Uncertain Tax Policy: Does Random Tax Policy Discourage Investment?” Economic Journal 109, no. 457 (1999): 372-93.

52. Robert Higgs, "Regime Uncertainty: Why the Great Depression Lasted So Long and Why Prosperity Resumed after the War," Independent Review 1, no. 4 (1997): 561-90.

53. As quoted by Higgs. 
fact that uncertainty increases when policies that would hamper economic growth become more likely. Had the feared policy changes actually occurred (with no uncertainty), the economic implications would have been even more serious. Some argue that regime uncertainty underlies the poor economic performance of the U.S. economy since the onset of the Great Recession. ${ }^{54}$

Many fear the implications of unprecedented (at least in the post-WWII era) budget deficits in the short term, coupled with severe fiscal imbalances in the long term, driven primarily by entitlement programs, such as Medicare, Medicaid, and Social Security. Many would agree that the U.S. is approaching a crossroads: Drastic and painful reforms are needed simply to constrain the federal government to the size it has maintained since the end of WW II. A not-implausible scenario is that the U.S. will become more like Western Europe, with the federal government possibly increasing in size (as a share of GDP) by more than 50 percent over the next two generations. ${ }^{55}$

A recent Wall Street Journal op-ed by prominent economists (all of whom have served important roles in government) chronicled the magnitude of the issues facing the U.S..$^{56}$-the federal debt, increased regulations, and the actions of the Federal Reserve. They wrote, "The problems are close to being unmanageable now. If we stay on the current path, they will wind up being completely unmanageable, culminating in an unwelcome explosion and crisis." This suggests that fears of regime uncertainty may not be unwarranted-although the scenarios are not nearly as extreme as the ones feared during the 1930s, as described by Higgs (e.g., fascism or communism). To date, attempts to address America's problems have been met with political stalemates, which contributed to the downgrading of U.S. debt and, according to an op-ed in the Chicago Tribune, could lead to yet another downgrade in $2013 .{ }^{57}$

\section{Destructive Entrepreneurship, Tax Policy Uncertainty and Rent-Seeking}

WILLIAM BAUMOL'S SEMINAL work in the area of rent-seeking and entrepreneurship appeared in $1990 .{ }^{58}$ Building on the classic work of Schumpeter, Baumol argued that entrepreneurship can be divided into productive, unproductive, and destructive

54. University of Tennessee Finance Professor Mahmoud Haddad suggests that business owners are waiting for election results before opening or expanding businesses. See Ned B. Hunter, "Businesses waiting on November results," Jackson Sun, August 25, 2012.

55. The 2012 Long-Term Budget Outlook, June 2012 (Washington, DC: Congressional Budget Office), 146, http://www.cbo.gov/sites/default/files/cbofiles/attachments/LTBO_One-Col_2.pdf.

56. George P. Shultz, Michael J. Boskin, John F. Cogan, Allan H. Meltzer, and John B. Taylor, "The Magnitude of the Mess We're In,” Wall Street Journal, September 16, 2012.

57. Steven C. Johnson and Daniel Bases, "U.S. faces rating cut if 2013 budget talks fail: Moody's," Chicago Tribune, September 11, 2012.

58. William J. Baumol, “Entrepreneurship: Productive, Unproductive, and Destructive," Journal of Political Economy 98, no. 5 (October 1990), part 1,893-921. 
activities. ${ }^{59}$ Before Baumol, the focus within the entrepreneurship literature was almost exclusively on the productive side. Baumol chronicled great innovations made over wide swaths of history, but he notes that in many cases these innovations did little to improve the lots of most individuals, and little effort was made to disseminate these inventions to the masses or to use inventions to increase productivity. Baumol argued that political and cultural institutions play a key role in whether or not innovations are geared toward improved productivity and economic growth. In many preindustrial societies, the path to wealth was through rulers, and not the marketplace; this fostered entrepreneurial rent-seeking, which does not increase the size of the economic pie. Neither did military innovations, which were often remunerative for individuals but not for society at large. Governments rewarded military innovations, but the wars in which these innovations were employed often slowed economic development. An important insight from Baumol is that it is not just the degree of entrepreneurship that is central to economic growth, but also the allocation of entrepreneurship between constructive activities and unproductive or destructive ones.

Although Baumol does not address the issue of politically induced economic uncertainty, our hypothesis is that policy uncertainty is a signal that government is open for business: Policies are going to change, and politicians are receptive to policy changes. With little policy uncertainty, higher returns may be sought from investing in productive activities. However, when government is receptive to policy changes, the returns from rent-seeking (through lobbying, political action committees, etc.) may be more appealing. When policy uncertainty does not otherwise exist, politicians sometimes manufacture it. For example, legislators sometimes propose "milker bills." These bills are not intended to actually become law, but rather to extort or "milk" rents from interested parties in exchanged for killing the proposal. ${ }^{60}$ Thus, even a period with stable policies may contain substantial policy uncertainty and concomitant losses to the economy from rent-seeking and unproductive entrepreneurship.

In a 1991 study, Kevin Murphy, Andrei Shleifer, and Robert Vishny reported evidence that supports Baumol's conception of unproductive or destructive

59. Baumol places little emphasis on the distinction between unproductive entrepreneurship and destructive entrepreneurship. Unproductive activities would include simple rent seeking, where resources are wasted. Although Baumol is not clear on this, destructive entrepreneurship could likely include rent seeking that successfully results in destructive economic policies-such as trade restrictions, or even war. Destructive entrepreneurship and unproductive entrepreneurship are not restricted to rent seeking: For example, governments could offer contracts or rewards for wasteful or harmful entrepreneurial activity. On the destructive side, Baumol provides the hypothetical example of a medieval baron who gains wealth "from the adoption of a novel bellicose technique" (p. 904).

60. See Fred S. McChesney, "Rent Extraction and Rent Creation in the Economic Theory of Regulation,” Journal of Legal Studies, 16 (January 1987), 101-18. 
entrepreneurship..$^{61}$ They looked at career decisions across different countries and found that occupational choice is influenced by the relative returns in different sectors of the economy. They argued that in environments in which rent-seeking is a dominant path to wealth, more people will be drawn into law; in societies in which the dominant path to wealth is through the marketplace, fields like engineering will be more attractive. Indeed, Murphy et al. found that nations with more law students grow more slowly than nations with more engineering students. They suggested that the slowdown in economic growth over the past forty years in the United States may be due in part to a shift in the allocation of human capital toward disciplines that are more likely to be involved in rent-seeking and other nonproductive activities.

In related work, Russell Sobel examined relationships between the characteristics of political and economic institutions for U.S. states and both productive and unproductive entrepreneurial activity. ${ }^{62}$ His findings were consistent with Baumol's: He found that sound institutions are associated with shifts in entrepreneurial activity from unproductive or destructive areas to constructive ones. He did not, however, relate Baumol's work to the question of policy uncertainty.

To our knowledge, Rodrik is the only one to make a connection between uncertainty and rent-seeking. Focusing on poorer nations, Rodrik noted that positive policy changes may yield increased investment. However, that new investment also creates vested interests in the new policy, and those groups will expend resources to see that the policies that favor their industry are extended-or that new policies benefiting their industry are enacted. While rent-seeking may promote stable policies, it also is a drag on the economy. It would be better to have an institutional arrangement that made further policy changes more difficult while signaling policy commitment by the government; then stable policy would be fostered without extracting wasted resources through rent-seeking.

61. Kevin M. Murphy, Andrei Shleifer, and Robert W. Vishny, "The Allocation of Talent: Implications for Growth,” Quarterly Journal of Economics 106, no. 2 (May 1991): 503-30.

62. Russell S. Sobel, "Testing Baumol: Institutional Quality and the Productivity of Entrepreneurship," Journal of Business Venturing 23 (2008): 641-55. 


\section{IIII. EMPIRICAL EXERCISE: TAX POLICY UNCERTAINTY AND RENT-} SEEKING

NEXT WE EXAMINE empirically our hypothesis from the end of the previous section: Namely, does uncertainty (and policy uncertainty in particular) induce increased efforts to lobby government? As discussed earlier, we posit that policy uncertainty is a signal not only that policies may soon change, but that efforts to influence policy are more fruitful than at other times. The logic follows that cost-benefit analyses will show, relative to periods with less policy uncertainty, greater returns from rentseeking than from more productive activities. Thus, policy uncertainty not only lowers the return on productive investments but may also raise the return on unproductive investments. In addition, as McChesney emphasized, rents may be extracted or "extorted" even if policies remain stable. The extracted rents may be the price paid for maintaining current policy.

We have found evidence that uncertainty (especially financial and tax policy uncertainty) does indeed encourage additional rent-seeking, which could be added to the economic costs of uncertainty. In other instances, however, uncertainty measures do not yield estimates that are statistically different from 0 . In these instances, the results should be viewed as inconclusive, not as a rejection of our hypothesis. In fact, the sign of the estimated coefficients in all six specifications is consistent with our hypothesis, but the small sample sizes involved mean that some coefficients were not estimated with enough precision for statistical significance.

\section{Rent-Seeking Proxies}

ONE PROXY FOR rent-seeking is the number of political action committees (PACs) and their spending levels. As shown in Figure 2, PACs and PAC spending rose rapidly from 1977 through the mid-1980s. For the next decade or so, the numbers remained stable. Around the turn of the century, however, PAC activity resumed its growth pattern. Sobel argued that the federal budget surpluses of the 1990s were correlated with a lack of PAC growth.$^{63}$ Notably, the relatively stable levels of PAC activity began after passage of the Tax Reform Act of 1986; this was also a period of relatively low and stable uncertainty, as measured by BBD (see Figure 1). BBD's uncertainty indices generally rose, and became more volatile, beginning in 2000.

One issue raised by these data is the possible reallocation of resources from productive entrepreneurs to nonproductive rent seekers. Other proxies for unproductive entrepreneurship include lobbying and PAC expenditures. However, none of these proxies capture all rent-seeking efforts, which would include illegal activity as well as lobbying by government agencies to protect or expand their budgets. ${ }^{64}$ To

63. Russell S. Sobel, "Can Public Choice Theory Explain the U.S. Budget Surpluses of the 1990s?" Journal of Public Finance and Public Choice 23, no. 3 (2004): 169-82.

64. For an example, see investigative journalist Brody Mullins's interview with Brian Lamb, in which he documents large-scale lobbying efforts of the U.S. military, using taxpayer dollars. 
FIGURE 2. PACS AND PAC SPENDING

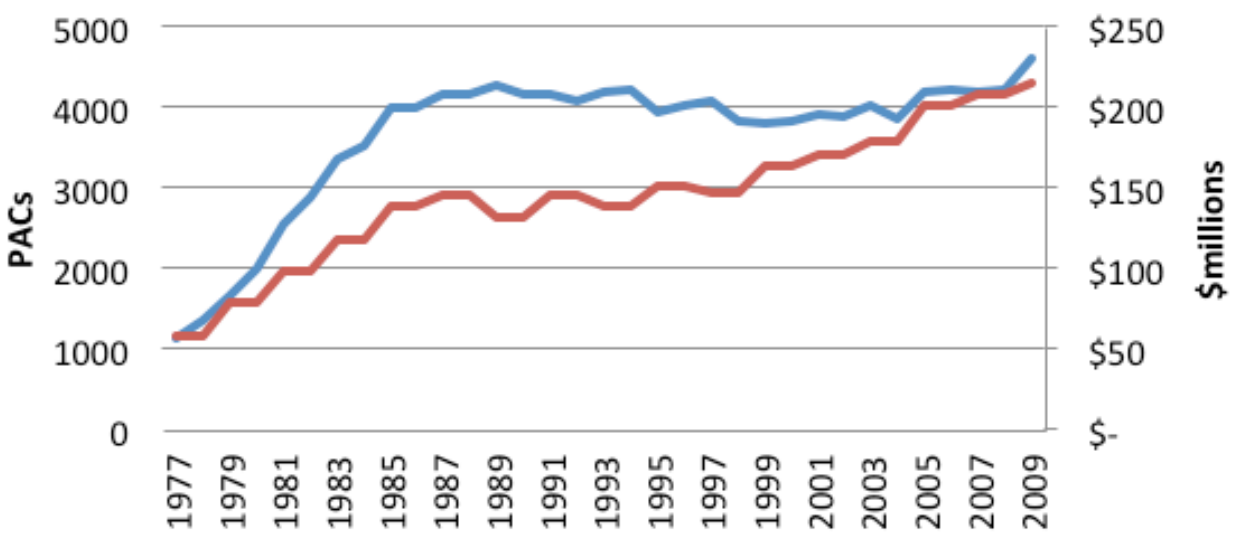

Source: FEC

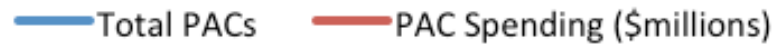

the extent that uncertainty fosters an environment conducive to rent-seeking, there may be wide-scale economic implications. As noted earlier, research has found that institutional characteristics can affect occupational choice-for example, between engineering and the law. ${ }^{65}$ While lawyers may be of great value to society, at the margin lawyers are more likely to be associated with rent-seeking behavior, whereas engineers are more likely to be engaged in productive activities (broadly defined). Our hypothesis is that increased uncertainty should result in both an increase in unproductive entrepreneurship and a decrease in productive entrepreneurship. Here, however, we only examine the unproductive side.

\section{Empirical Results}

WE PERFORMED A series of regressions to test our hypothesis. As shown in column 1 of Table 2, we regressed the log change in the number of PACs against the lagged log change in tax expenditures as a share of GDP, as well as a time trend. ${ }^{66}$ This first baseline specification did not include any measures of uncertainty. The estimated coefficient on the tax expenditure measure suggests that a one percent increase in lagged tax expenditures as a share of GDP was associated with a modest 0.02 percent increase in the number of PACs. However, this estimate is not statistically different from 0 . One possibility is that as tax expenditures grow, more is at stake,

65. Murphy, Shleifer, and Vishny, "Allocation of Talent."

66. A couple of technical notes: (a) PACs and lobbying could also be drivers of uncertainty. We used lags of the uncertainty measures in an attempt to isolate the effect of uncertainty on rent seeking, as opposed to the other way around. (b) A more sophisticated approach would employ two-stage least squares to identify parameters. However, with small samples, two-stage least squares tends to yield biased estimates. 
so more resources are expended to preserve or expand them. The results here do not support this hypothesis. In columns 2 to 6 , as uncertainty measures are added to the model, the importance of this tax expenditure measure remained small and was never statistically different from 0 . It may be that many tax expenditures are so ingrained that substantial lobbying may not be required for them to persist. ${ }^{67}$

In column 2, the log of the lag of BBD's overall uncertainty measure is added to the model. The estimate suggests that a one percent increase in the uncertainty measure is associated with a 0.07 percent increase in the number of PACs. However, this too is not statistically different from 0 . Columns 3 and 4 also report statistically insignificant results for both economic and political uncertainty. Note that the sign of the estimated coefficient on the uncertainty measure is positive in all of these specifications, consistent with our hypothesis. These results are best viewed as inconclusive, due to a lack of statistical precision. With such small sample sizes, it would not be surprising to find statistically insignificant results when a true positive relationship does exist.

Results from columns 5 and 6 are more interesting. Both show positive and statistically significant relationships between uncertainty measures and the number of PACs. Column 5 suggests that a one percent increase in financial uncertainty will lead to a 0.04 percent increase in the number of PACs. By far the strongest result is from column 6 , which focuses on our tax uncertainty measure. Here, a one percent increase in tax policy uncertainty is associated with a 0.2 percent increase in the number of PACs. This estimate carries strong statistical significance. In addition, our tax uncertainty measure does more than any other to increase the explanatory power of the model. The coefficient of determination rises from between 0.24 and 0.29 with the other uncertainty measures and to 0.51 with our tax policy uncertainty measure. These results support our hypothesis. The results are by no means definitive; they represent a limited approach, with the hope of spurring further investigation.

67. Tax expenditures are more akin to entitlement spending than to other programs with approved budgets. In most instances, they are a function of the behavior of individuals and firms and are not constrained by budget appropriations. Like entitlement spending, they do not rely on annual actions by Congress or on the passage of a budget. Of course, this is not true for temporary tax expenditures, which can expire without legislative action. 
TABLE 2. THE RELATIONSHIP BETWEEN UNCERTAINTY AND THE NUMBER OF POLITICAL ACTION COMMITTEES

Dependent Variable: log difference in the number of PACs.
(1)
(2)
(3)
(4)
(5)
(6)

$\Delta \log ($ tax expendi-

$0.023-0.026$

$-0.060$

$-0.056$

$-0.093$

$-0.117$

tures as $\%$ of GDP)

$(0.657) \quad(-0.273)$

$(-0.595)$

$(-0.579)$

$(-0.934)$

$(-1.326)$

Time Trend

$-0.003^{* * *}$

$0.002^{* *}$

$0.003^{* *}$

$0.003^{* *}$

$0.003^{* *}$

$0.004^{* * *}$

$(-2.900)$

(2.200)

(2.800)

(2.600)

(2.800)

(4.400)

$\triangle \log (\mathrm{BBD}$

Uncertainty)

0.074

(1.369)

$\triangle \log (\mathrm{BBD}$

Economic

Uncertainty)

0.023

(1.272)

$\triangle \log ($ BBD Political

Uncertainty)

0.046

(1.444)

$\Delta \log ($ BBD Financial

Uncertainty)

(1.870)

$\Delta \log (\operatorname{Tax}$

Uncertainty Index)

$0.209^{* * *}$

(3.168)

Constant

$5.672^{* *}$

$-4.488$

$-5.652^{*}$

$-5.174$

$-5.608^{* * *}$

$-8.774^{* * *}$

(2.323)

$(-1.541)$

$(-2.010)$

$(-1.849) \quad(-2.077)$

$(-3.108)$

Observations

32

23

23

23

23

21

R-squared

0.172

0.238

0.227

0.244

0.287

0.511

Sources: BBD data in conjunction with authors' calculations from data from Google News, the President's Budget, and the U.S. Bureau of Economic Analysis.

All logged right-hand side variables are one-year lagged first differences; $t$-statistics are in parentheses; $t$-values with the appropriate degrees for freedom are used for determining statistical significance (since the sample sizes are small).

* Significant at the .10 level.

** Significant at the 05 level.

*** Significant at the 01 level. 
This same analysis was also performed with lobbying expenditures as the dependent variable and again with spending by PACs as the dependent variable. The model for lobbying yields positive estimates for all of the uncertainty measures, and for BBD's overall uncertainty measure the estimate is statistically significant. For PAC spending, we found positive and statistically significant estimates for our tax policy uncertainty measure and for BBD's overall uncertainty measure. These results also lend support to our hypothesis, while relying on even fewer data than used in Table 2-generally just 12 or 13 observations (as opposed to the 21 or 23 observations for the estimates in Table 2) ${ }^{68}$ The small sample size is likely a key reason why some of the estimates are statistically insignificant. In sum, we find that these results are generally consistent with our hypothesis that tax policy uncertainty promotes additional rent-seeking. With more data and better measures of rent-seeking, we suspect to find stronger results. However, it is noteworthy that this limited approach nonetheless yields positive and statistically significant estimates in some cases, and in particular for the tax policy uncertainty index.

\section{CONCLUSION AND IMPLICATIONS FOR TAX REFORM}

THE ECONOMIC LITERATURE finds that policy uncertainty is harmful to the economy in a variety of ways. Clearly, uncertainty discourages investment and results in the misallocation of resources. As mentioned earlier, Baker, Bloom, and Davis show that policy uncertainty can help explain the United States' lackluster growth (in jobs and overall economic activity) in recent years. In addition to the other avenues by which policy uncertainty harms the economy, we argue that it fosters rent-seeking and unproductive entrepreneurship. Our argument is supported by an empirical examination of this issue, which finds correlations between increased tax policy uncertainty and PAC activity.

What can be done to lessen tax policy uncertainty? Enduring fundamental tax reform would certainly help. Aside from policy uncertainty, there are many good reasons to support tax reform. Although recent years have been marked by great political discord, few of any political bent would dispute the contention that the U.S. federal income tax is unfair, inefficient, and needlessly complex, and that it raises far less revenue than Congress commits to spend. These are reasons enough for tax (and spending) reform. However, tax policy uncertainty is another, often overlooked, reason. Broad principles for fundamental tax reform are beyond the scope of this paper. Instead, we consider proposals that may promote a more stable, more certain tax system, in which opportunities for rent-seeking are diminished.

68. PAC spending is measured over two-year election cycles. The PAC spending model is estimated in $\log$ form, instead of first differences, because autocorrelation does not appear to be present. When including the number of PACs or lobbying expenditures as the dependent variable, the models are estimated in first differences because the null hypothesis that the residuals are not serially correlated is soundly rejected. 
The Tax Reform Act of 1986 (TRA 86) was America's most recent fundamental tax reform. TRA 86 was far from perfect, but it closed loopholes, broadened the tax base, and lowered rates. Studies have shown that it greatly reduced economic inefficiencies, and some argue that it laid the foundation for the U.S.'s strong economy during the remainder of the 1980s (as well as the 1990s). For example, Federal Reserve Bank of Dallas economist Anil Kumar found that TRA 86 substantially reduced overall deadweight loss in the economy. ${ }^{69} \mathrm{MIT}$ economics professor James Poterba found that the reform substantially lowered inefficiencies in the housing market. ${ }^{70}$ However, a major shortcoming of TRA 86 was that the new tax system remained malleable. Fichtner and Feldman argued that this was partly the result of TRA 86's failure to tackle the largest and most politically sensitive tax deductions-such as the mortgage interest deduction and the exclusion of employer-provided health insurance. ${ }^{71}$ As soon as many of the loopholes were closed, lobbyists and Congress were hard at work to reopen them. As the twentieth anniversary of TRA 86 approached, the report of the President's Advisory Panel on Federal Tax Reform noted that Congress had, since TRA 86, amended the tax code approximately 15,000 times. ${ }^{72}$ That is more than twice a day, including weekends! In their detailed review of the effects of TRA 86, economists Alan Auerbach and Joel Slemrod concluded that "Even the simplification potential of radical tax reform depends on how enduring a simple, broad-based tax can be, in the face of constant political pressure to reintroduce special 'encouragements' or to redistribute the tax burden." ${ }^{73}$

The problem of maintaining a reformed tax code stems from the fact that economic efficiency does not have a well-organized or focused interest group to represent it. Economic efficiency produces great benefits, but these benefits are widely dispersed, putting it at a political disadvantage. By contrast, carve-outs and other special provisions that make the tax system more inefficient, complex, and unfair often confer concentrated benefits on a relatively small group. While the costs of such measures generally far outweigh the benefits, the beneficiaries are more

69. Anil Kumar, "Labor Supply, Deadweight Loss and Tax Reform Act of 1986: A Nonparametric Evaluation using Panel Data," Journal of Public Economics 92 (2008): 236-53.

70. James M. Poterba, “Taxation and Housing: Old Questions, New Answers.” American Economic Review 82, no. 2 (May 1992): 237-42.

71. Jason Fichtner and Jacob Feldman, "When are Tax Expenditures Really Spending? A Look at Tax Expenditures and Lessons from the Tax Reform Act of 1986," Mercatus Center Working Paper No. 11-45, November 2011.

72. Simple, Fair, and Pro-Growth: Proposals to Fix America's Tax System (Report of the President's Advisory Panel on Federal Tax Reform, November 2005), http://govinfo.library.unt.edu /taxreformpanel/final-report/index.html

73. Alan J. Auerbach and Joel Slemrod, "The Economic Effects of the Tax Reform Act of 1986," Journal of Economic Literature 35, no. 2 (June 1997): 589-632. 
concentrated and the benefit per beneficiary is often much larger. These measures lend themselves to more effective lobbying. ${ }^{74}$

The fact that the tax code is constantly under revision can have several harmful effects on the economy. First, even an otherwise simple, fair, and efficient tax system fails to instill confidence if the system is in perpetual motion. A system that is amended twice a day, on average, is inherently uncertain. Second, the constant amending of the tax system often undoes the benefits from reform by opening and widening loopholes-and, more generally, by reducing the tax base. By some measures, tax expenditures totaled over $\$ 1.2$ trillion for $2011 .^{75}$ That is, the array of special provisions, including credits and deductions, resulted in forgone federal revenues equal to more than 50 percent of the $\$ 2.3$ trillion in federal revenues actually collected..$^{76}$ These tax loopholes result in greater inefficiencies and higher tax rates-or, in recent years, greater borrowing and greater debt. Third, the constant changes to the tax code are the result of rent-seeking. As McChesney emphasized, rents are also extracted to maintain provisions in the tax code (i.e., to not have them amended). ${ }^{77}$ Rent-seeking represents a further loss to the economy through the shifting of resources from productive activities to unproductive or destructive ones. As Baumol argued, societies that rely heavily on institutions that reward rentseeking tend to stagnate; societies that rely on institutions whose wealth is achieved through private competitive markets tend to prosper.

\section{Making Tax Reform Enduring}

Nobel laureate Milton Friedman was a longtime proponent of a flat tax with no deductions, other than a personal exemption and legitimate business expenses. ${ }^{78} \mathrm{He}$ favored a flat tax for a variety of reasons, but partly because (he argued) such a tax

74. A classic example is the U.S. sugar industry, which reaps huge benefits from U.S. tariffs on imported sugar. In some cases, however, the groups benefiting from special tax treatment-for example, the nontaxation of employer-provided health insurance, and the mortgage interest deduction-are large. While the beneficiaries here are not nearly as concentrated as in the case of sugar tariffs, real estate and medical associations are able to form formidable lobbies. Mancur Olson, The Logic of Collective Action: Public Goods and the Theory of Groups (Cambridge, MA: Harvard University, 1965).

75. Donald B. Marron, "How Large Are Tax Expenditures? A 2012 Update," Tax Notes, April 9, 2012.

76. Tax expenditures are a static measure. Thus, eliminating all tax expenditures would raise less revenue than the full value of the tax expenditures. Also, tax expenditures are not prima facie bad. Reasonable arguments could be made to defend many of the provisions on grounds of either equity or efficiency. Examples include the Earned Income Tax Credit and the charitable deduction.

77. Fred S. McChesney, "Rent Extraction and Rent Creation in the Economic Theory of Regulation," Journal of Legal Studies, 16 (January 1987): 101-18.

78. The "flat tax," as proposed by Robert Hall and Alvin Rabushka, had consumption as its base. However, a flat tax could also be applied to an income tax base. A flat tax is not a proportional tax (with respect to its base), but is in fact progressive because of a zero bracket, or personal exemptions. With an income base, for example, taxes as a share of income rise with income. 
system would be more resistant to tinkering. More recently, the Mirrlees Review's volume Tax by Design supported Friedman's sentiment, stating that "Uniform taxation also simplifies the politics of decision-making and makes tax policy less vulnerable to lobbying pressure and short-term political considerations. A system with differentiated rates invites interest groups to lobby for lower rates for their own products, or at least rates as low as those on other preferentially treated commodities."79 Friedman, however, was not sanguine about the prospects of such a tax system. As he noted in a 1982 Newsweek column, such a system "arouses intense opposition from powerful special interests created by the existing tax system: recipients of so-called charitable contributions, homeowners, the housing industry, institutions financing housing construction, the myriad of other producers and beneficiaries from tax shelters, tax lawyers and accountants, and last but not least, politicians who raise campaign funds from special-interest groups seeking to retain existing loopholes or create new ones." ${ }^{80}$ McChesney echoed and expounded on Friedman's cynicism regarding the political process. ${ }^{81}$

Friedman concluded that the only way to achieve an enduring flat tax is by amending the Constitution. Randall Holcombe also championed a "fiscal constitution" to combat welfare losses from rent-seeking. ${ }^{82}$ Even a tax reform that is not nearly as simple and transparent as Friedman's could be made more enduring through constitutional changes. For example, a constitutional amendment that requires supermajorities to pass laws pertaining to tax expenditures could make tax reform more successful. Amending the Constitution is a tall order, however; other measures, while not as effective as a constitutional provision, may be more attainable.

One avenue toward more enduring tax reform could come from reforming the budget process. The budget process has undergone numerous revisions in recent decades, with limited success, but hope springs eternal. One reason tax policy is uncertain is that the current tax system is insufficient to cover current and projected spending. This has as much to do with the spending side of the budget as it does with the tax side. Congress regularly games the system by producing bills designed to receive unrealistically favorable analysis by $\mathrm{CBO}$ and JCT. This contributes to long-term deficits, even when legislation appears to meet requirements that it not

79. James Mirrlees et al., Tax by Design: The Mirrlees Review. Oxford: Oxford University Press, 2011, p. 154 .

80. Milton Friedman, "How Flat is Flat?” Newsweek, August 2, 1982, p. 52.

81. Fred S. McChesney, "What's Mine is Theirs: The Ever-Shimmering Mirage of Lasting Tax Reform," Library of Economics and Liberty, April 4, 2005, http://www.econlib.org/library/Columns/y2005 /Mcchesneytaxreform.html.

82. See Randall G. Holcombe, "Tax Policy from a Public Choice Perspective," National Tax Journal 51, no. 2 (June 1998): 359-71. Holcombe suggests that a broad-based retail sales tax or a value-added tax may be more resistant to rent seeking. 
adversely affect the deficit. A reform to address this problem would require CBO and JCT to "score" proposed legislation over the next ten years both as written and as fully phased in; the score that is less favorable would be operative. Such a rule could reduce the chicanery that characterizes the budget process.

Other reform options would limit the use of tax deductions. Martin Feldstein, Daniel Feenberg, and Maya MacGuineas (2011) have proposed limiting the use of deductions by setting an itemized deduction ceiling of 2 percent of total income. ${ }^{83}$ They claim that this reform would decrease the number of itemized filers by 75 percent, from 48 million to 13 million. Economist Len Burman of Syracuse University (and founder of the Tax Policy Center) suggests a "three strikes and you're out" rule for tax deductions and credits: His proposal would give Congress the option of renewing tax provisions three times, and after that the provision must either be made permanent or eliminated. Burman recognizes that this proposal is not fundamental tax reform, but it might reduce the uncertainty created by the growing number of expiring tax expenditures. ${ }^{84}$

83. Martin Feldstein, Daniel Feenberg, and Maya MacGuineas, "Capping Individual Tax Expenditure Benefits,” NBER Working Paper 16291, Cambridge, MA, April 2011, http://www.nber.org/papers /wl6921.pdf.

84. Tax Vox (blog), Tax Policy Center; "Three Strikes and You're Out for Tax Extenders," blog entry by Len Burman, February 1, 2012, http://taxvox.taxpolicycenter.org/2012/02/01/three-strikes-and -youre-out-for-tax-extenders/. 


\section{APPENDIX}

SUPPOSE THAT A venture capitalist has the option to invest in either ethanol or solar energy. The net return on investment depends on the outcome of the election: If candidate A wins tax subsidies for ethanol will be expanded, but if candidate B wins tax subsidies for solar energy will be expanded. The combined probability of winning and losing is equal to one. The net return on investing in the winning subsidy ex-ante and ex-post is the following:

Ex ante $=\operatorname{Pr}($ win $) \cdot x-\operatorname{Pr}($ lose $) \cdot z=\operatorname{Pr}($ win $) \cdot x-(1-\operatorname{Pr}($ win $)) \cdot z$

Expost $=y$

$\operatorname{Pr}$ (win) signifies the probability that the tax subsidy of interest is expanded while $\operatorname{Pr}($ lose) signifies the probability that the tax subsidy is not expanded. Note that $\mathrm{x}$ signifies the payoff value of investing in the increased tax subsidy of interest before its enactment; $y$ signifies the payoff value of investing in the increased tax subsidy of interest after its enactment; and $\mathrm{z}$ signifies the payoff loss of investing in the increased tax subsidy of interest that is not enacted. Thus, a risk-neutral investor will choose to invest ex ante if:

$\operatorname{Pr}($ win $) \cdot x-(1-\operatorname{Pr}($ win $)) \cdot z \geq y$

» $\operatorname{Pr}($ win $) \cdot(x+z)-z \geq y$

$» x \geq(y / \operatorname{Pr}($ win $))-(z-z / \operatorname{Pr}($ win $))$

Equation 3 provides the payoff necessary for a venture capitalist to invest in ethanol or solar energy prior to the election. When there are no losses from selecting the losing investment, then the decision to investment will be selected by the following equation:

if $z=0$, then $x \geq y / \operatorname{Pr}($ win $)$

and if $\operatorname{Pr}($ win $)=0.5$, then $x \geq 2 y$

However, if investments are to some degree irreversible, as many economists assert, thereby rendering positive losses to malinvestment, then the payoff to invest must increase, ceteris paribus.

If $z>0$, then $x \geq 2 y+z$

This stylized example shows how the problem of irreversibility on investments coupled with policy uncertainty may lead investors to delay decision-making until payoffs are more certain. 